\title{
Hubungan Penggunaan fitur Insta Story Sebagai Media Promosi dengan Minat Beli Produk Wellborn
}

\author{
${ }^{1}$ Dea Permatasari \\ 1,2Prodi Ilmu Public Relations Fakultas Ilmu Komunikasi, Universitas Islam Bandung, \\ Jl. Tamansari No. 1 Bandung 40116 \\ e-mail: ${ }^{1}$ deaprtms@gmail.com
}

\begin{abstract}
Nowadays, the use of social media, one of which is the Instagram application in the Insta Story feature, has many advantages such as its wide coverage, because it uses online facilities, and its continuous connectivity. The presence of this new media makes it easier for humans to communicate daily. In the current era, companies need to utilize their resources optimally, and try to influence consumers' buying interest through the promotion of Wellborn products. Current technological developments make it easier for consumers to find information about a product on the market. The theory used in this research is the theory of Uses and Gratification. The research method used is quantitative correlational studies applying the rank Spearmen correlational formula to test whether there is the relationship between Attraction, Convert, and Transfrom, in using the insta story feature as a promotional medium, with the interest in buying Wellborn products. Sampling was carried out on 67 respondents as well as viewers. Based on the results of the study, it is showed that there was a significant relationship between the use of Insta Story features as a media promotion and the interest in buying Wellborn products; with a total coefficient value of 66,283 .
\end{abstract}

Keywords: buying interest, Instagram, Insta Story, Promotion

\begin{abstract}
Abstrak. Penggunaan media sosial saat ini mempunyai keunggulan salah satunya yaitu aplikasi instagram dalam fitur insta story yang cakupannya luas menggunakan fasilitas online dan terhubung kapanpun. Kehadiran media baru (new media) semakin memudahkan manusia dalam berkomunikasi sehari-hari.Di era sekarang perusahaan perlu memanfaatkan sumber dayanya dengan optimal, serta berusaha mempengaruhi minat beli konsumen melalui adanya promosi produk Wellborn. Perkembangan teknologi saat ini jauh lebih memudahkan para konsumen untuk mencari informasi tentang suatu produk yang ada di pasaran. Teori yang digunakan dalam penelitan ini adalah teori Uses and Gratification. Metode penelitian yang digunakan penulis dalam penelitian ini adalah kuantitatif studi korelasional dan menggunakan rumus korelasional rank spearmen untuk menguji apakah ada hubungan antara Attraction, Convert, dan Transfrom penggunaan fitur insta story sebagai media promosi dengan minat beli produk Wellborn. Pengambilan sample dilakukan kepada 67 orang responden followers sekaligus viewers. Berdasarkan hasil penelitian, menunjukkan bahwa terdapat hubungan yang signifikan antara Penggunaan Fitur Insta Story sebagai Media Promosi dengan Minat Beli Produk Wellborn dengan nilai total koefisien sebesar 66,283.
\end{abstract}

Kata kunci: Minat beli, Instagram, Insta Story dan Promosi

\section{Pendahulan}

Wellborn merupakan industri
pakaian yang mengeluarkan produk seperti kaos, kemeja, topi, celana, jaket, dan tas. Wellborn sebagai salah satu perusahaan yang berusaha untuk mengkomunikasikan nilai kompetitif 
produknya kepada konsumen, agar timbul keinginan atau minat untuk membeli produknya. Adapun salah satu produk dari Wellborn yang di promosikan melalui insta story-nya.

Menurut survei yang dilakukan marketing research mars Indonesia, muncul tiga brand terfavorit di Indonesia yaitu produk Cottonink, Wellborn dan Adorable Project. Dengan adanya persaingan antara satu sama lain, maka dari itu perusahaan dituntut untuk lebih kreatif dalam mencari sebuah ide untuk karya yang unik. Sehingga dapat bersaing secara sehat dalam memenuhi kebutuhan pasar yang berpotensi. Sebab jika pemasaran yang dilakukan itu berdampak baik, maka secara perlahan peminat pun akan tertarik untuk membeli produk barang atau jasa yang dipasarkan sebuah perusahaan. Perusahaan perlu memanfaatkan sumber dayanya dengan optimal, serta berusaha mempengaruhi persepsi konsumen melalui adanya suatu citra produk. Perkembangan teknologi saat ini jauh lebih memudahkan para konsumen untuk mencari informasi tentang suatu produk yang ada di pasaran. Perusahaan berlomba-lomba membuat citra merek yang positif. Sehingga harus mampu menciptakan produk dan promosi yang menarik agar produk dinilai penting oleh konsumen.

Proses tersebut dipengaruhi oleh

promosi yang dilakukan untuk memberikan informasi mengenai nilai kompetitif dari produk tersebut. Hal ini menjadi penting, karena proses inilah yang nantinya akan mempengaruhi konsumen untuk membeli sebuah produk. Bagaimana seorang marketer bisa mempengaruhi konsumen secara persuasif untuk menimbulkan minat beli, sehingga konsumen memutuskan untuk membeli produk tersebut. Pada saat ini setiap perusahaan menciptakan promosi melalui media sosial seperti instagram disamping biaya promosinya murah, namun dampaknya banyak masyarakat yang berminat melihat lalu membeli produk yang ditawarkan oleh perusahaan baik yang ada di Indonesia maupun mancanegara.

Fitur insta story ini diluncurkan sejak tahun 2016 dan mulai saat itu menjadi bagian penting pertumbuhan instagram. Kehadiran Insta Story diranah media sosial masih tergolong muda, namun bulan Juni 2017, berdasarkan data yang diambil dari Instagram, fitur tersebut sudah mampu mencetak angka 250 juta pengguna di seluruh dunia. Insta story membuat pengguna berusia dibawah 25 tahun menghabiskan lebih dari 32 menit sehari untuk instagram. Menurut salah satu survey yang dihimpun oleh tim riset tirto.id menjelaskan bahwa Insta Story menjadikan sebagai media yang tepat untuk beriklan.Indonesia jadi salah satu negara dengan pengguna InstaStory terbesar di dunia.Insta Story merupakan sebuah media promosi untuk mengkomunikasikan nilai kompetitif produk kepada konsumen yang menjadi followers akun tersebut yang akan mejadi sebuah penelitian ini adalah akun Wellborn. Dalam penelitian ini peneliti menggunakan salah satu fitur insta story untuk mengkomunikasikan nilai kompetitif agar timbul minat beli dari konsumen.

\section{Perumusan Masalah}

Berdasarkan latar belakang situasi yang telah diuraikan, maka dirumuskan permasalahan dalam penelitian sebagai berikut. "Apakah terdapat hubungan antara penggunaan fitur insta story dalam aplikasi instagram sebagai media promosi dengan minat beli produk Wellborn?" pada dasarnya, perumusan masalah ini merupakan gambaran mengenai hubungan antara penggunaan fitur insta story dalam aplikasi instagram sebagai media 
promosi dengan minat beli produk Wellborn yang hendak diteliti. Selanjutnya, pertanyaan besar dalam rumusan permasalahan ini di uraikan dalam pokok-pokok sbb.

1. Apakah terdapat hubungan antara Attraction penggunaan fitur insta story sebagai media promosi dengan minat beli produk Wellborn?

2. Apakah terdapat hubungan antara Convert penggunaan fitur insta story sebagai media promosi dengan minat beli produk Wellborn?

3. Apakah terdapat hubungan antara Transfrom penggunaan fitur insta story sebagai media promosi dengan minat beli produk Wellborn?

\section{Kajian Pustaka}

Penelitian ini bertitik tolak dari konsep dalam penelitian ini, penulis menggunakan teori Uses and Grafications Model (model kegunaan dan kepuasan) merupakan pengembangan dari model jarum hipodermik. Model ini tidak tertarik pada apa yang dilakukan media pada diri seseorang, tetapi ia tertarik pada apa yang dilakukan orang terhadap media. Khalayak secara aktif menggunakan media untuk memenuhi kebutuhannya. Studi dalam bidang ini memusatkan perhatian pada penggunaan (uses) media untuk mendapatkan kepuasan (gratifications) atas kebutuhan seseorang. Oleh karena itu, sebagian besar perilaku khalayak akan dijelaskan melalui berbagai kebutuhan (needs) dan kepentingan individu.

"Dalam teori Uses and Gratification bukanlah bagaimana media mengubah sikap dan perilaku khalayak, tetapi bagaimana media memenuhi kebutuhan pribadi dan sosial khalayaknya. Jadi bobotnya adalah pada khalayak yang aktif, yang sengaja menggunakan media untuk mencapai tujuan khusus (Effendy, 2003:289290)". Teori ini mengatakan bahwa pengguna media memainkan peran aktif untuk memilih dan menggunakan media. Jadi media adalah pihak yang aktif dalam komunikasi. Dalam teori ini audien aktif untuk menentukan media mana yang harus dipilih untuk memuaskan kebutuhannya. Tahapan-tahapan dalam media sosial online marketing menurut Shama Kabani adalah :

1. Attraction : Berusaha mendapatkan perhatian konsumen atau ingin terlihat menonjol. Contoh yang dapat digunakan yaitu penggunaan profile picture, cover photo, dan background yang menarik di media sosial yang digunakan.

2. Convert : Proses mengkoversi terjadi ketika kita menjadikan seorang yang tidak dikenal menjadi konsumen atau pelanggan. Seorang konsumen mungkin mengambil informasi tentang produk, tetapi belum tentu membeli produk yang ditawarkan, Seiring dengan berjalannya waktu, konsumen tersebut akan menjadi pelanggan. Dengan begitu, perusahaan harus bekerja secara konsisten mengkonversi seseorang menjadi konsumen bahkan pelanggan dari produk kita. Menurut Dorothi Wetzel Convert fitur Insta Story produk Wellborn adalah Proses mengkoversi terjadi ketika menjadikan seorang yang tidak dikenal menjadi konsumen atau pelanggan. Contoh dari convert yaitu. Caption, Comment, Follower, Hashtag, Like dalam akun instagram (Wetzel, 2016 : 129). Alat pengkonversi terbaik menurut Shama Kabani adalah Website perusahaan itu sendiri. 
Perusahaan tidak seharusnya terlibat di dalam media sosial online marketing jika tidak mempunyai website. Contoh dari convert itu sendiri apabila seorang konsumen sudah me-like page perusahaan dan menjadi follower yang ingin mengetahui update dari produk yang ditawarkan dari perusahaan itu sendiri.

3. Transform: Apabila kita sudah menguasai bagian attraction dan converting, kita perlu mengubah kesuksesan kita sebagai magnet untuk menarik para konsumen. Media sosial dibangun berdasarkan bukti sosial. Oleh karena itu, media sosial adalah cara yang tepat untuk merubah kesuksesan masa lalu menjadi daya tarik baru bagi perusahaan kita Kabani (2012:4).

Kutipan tersebut dapat menjelaskan bahwa media sosial online marketing adalah sebuah seni dan ilmu yang memanfaatkan internet untuk menyampaikan sebuah pesan sehingga kita dapat membuat orang lain untuk melakukan sebuah aktivitas, dimana contoh dari aktivitas tersebut adalah membeli produk atau jasa yang di tawarkan perusahaan. Selain itu, media sosial online menjadi sarana yang mudah diakses dan berguna sebagai jembatan komunikasi dalam hal meningkatkan brand awareness suatu produk, dan seringkali untuk memperkuat customer service. Dan terlebih lagi, media sosial online sangatlah murah dalam penggunaannya sehingga banyak perusahaan menggunakannya untuk strategi promosi perusahaan pada insta story-nya.

Minat beli pada dasarnya merupakan tendensi khalayak terhadap sesuatu. Minat adalah rasa senang atau tidak senang yang khalayak miliki terhadap sesuatu Severin dan Tankard menguraikan bahwa :

Minat beli merupakan kumpulan dalam berpikir, keyakinan dan pengetahuan. Di samping itu, sikap memiliki evaluasi positif maupun negatif yang disebabkan oleh komponen afeksi. Semua hal ini dengan sendirinya berhubungan dengan objek atau masalah yang disebut "the attitude object". Pengetahuan dan perasaan yang merupakan kluster dalam sikap akan menghasilkan tingkah laku tertentu. Objek yang dihadapinya pertama-tama berhubungan langsung dengan pemikiran dan penalaran seseorang, sehingga komponen kognisi melukiskan objek tersebut dan sekaligus dikaitkan dengan objek-objek sekitarnya Tankard, $2011:$ 451).

\section{Metode dan Sasaran Penelitian}

Dalam penelitian ini penulis menggunakan metode korelasional. Metode korelasional yaitu metode yang meneliti hubungan antara variabel variabel hubungan yang dicari yang disebut korelasi. Metode korelasional bertujuan meneliti sejauhmana hubungan pada satu faktor berkaitan dengan variasi pada faktor lain (Rakhmat, 2007:27). Metode korelasional digunakan karena peneliti ingin mengetahui apakah terdapat hubungan antara penggunaan fitur insta story dalam aplikasi instagram sebagai media promosi dengan minat beli produk Wellborn.

"Populasi adalah totalitas dari semua objek atau individu yang memiliki karakteristik tertentu, jelas dan lengkap yang akan diteliti" (Hasan, 2002: 58). Adapun Populasi yang diambil dalam penelitian ini adalah pengguna fitur insta story sebagai media promosi dengan minat beli produk Wellborn. Di instagram milik Wellborn 
dengan jumlah 210. Jumlah populasi tersebut di dapat dari data penelitian sesuai dengan berlakunya waktu fitur insta story yang hanya satu hari yang di mana peneliti mengambil populasi sebanyak 210 followers sebagai viewers Wellborn yang melihat dan membeli produk dari fitur insta story Wellborn pada tanggal 12 Juli 2018. Menentukan populasi itu sesuai dengan definisi peneliti sesuai dengan fokus penelitiannya menurut Dr.Zulfebrigez., Drs., M.Si dosen statistik fikom Unisba, jadi bukan berarti semua followers nya harus jadi responden tapi harus followers yang otomatis menjadi viewers. Untuk penarikan sampel dalam penyebaran angket atau kuesionernya memakai random sampling. Random sampel bisa dipakai jika ada kerangka sampel yang memuat semua anggota populasi (Elvinaro, 2010:172), yang dalam penelitian ini yakni pengguna fitur insta story dalam aplikasi intagram yang pernah melihat atau membeli produk Wellborn diinstagram milik Wellborn dengan jumlah 210, selama proses penelitian yakni tanggal 12 Juli 2018 karena fitur insta story yang ada di Instagram berlaku hanya satu hari sehingga total sebagai viewers yang melihat dan membeli produk melalui fitur insta story sebanyak 210 followers Wellborn. Sehingga penghitungan sampel menggunakan rumus Slovin berikut ini untuk menghitung ukuran sampel dari populasi yang diketahui jumlahnya. Umumnya sampling error maksimal adalah pada presisi $10 \%$ dengan tingkat kepercayaan $90 \%$ maka berdasarkan rumus sederhana dengan tingkat kepercayaan 90\%. Jadi sampel yang akan digunakan adalah sebanyak 67 responden.

\section{Temuan Penelitian}

Pada penelitian ini angket diberikan kepada 67 orang responden yang didominasi responden yang berjenis kelamin perempuan sebanyak 35 orang atau $52,2 \%$. dan sisanya adalah laki-laki sebanyak 32 orang atau $47,8 \%$. Dengan demikian viewers yang melihat dan membeli produk melalui fitur insta story Wellborn adalah kaum perempuan. Berdasarkan hasil wawancara dengan pihak Wellborn alasan banyaknya yang menjadi viewers. Menurut pihak Wellborn dalam wawancaranya mengatakan :

Yang menjadi viewers promosi produk di insta story Wellborn biasanya sih perempuan, hal tersebut bisa dilihat dari banyaknya yang masuk atau mengikuti insta story kami. Mungkin produk yang di promosikan oleh kami melalui media tersebut universal karena Wellborn tidak menentukan atau memprioritaskan segmen prodak untuk laki-laki. Oleh karena itu mungkin salah satu banyaknya viewers dari kaum perempuan. Selain itu, kami sendiri cukup sadar bahwa dalam segi belanja online atau melihat produk promosi secara online kebanyakan adalah kaum perempuan dibandingkan kaum lakilaki. Mungkin naluri seorang wanita dalam segi belanja baik online maupun tidak sangat tinggi dibandingkan lakilaki. (Hasil wawancara dengan Randi Mustafa, Markom Wellborn, 10 Agustus 2018).

Dari kutipan tersebut dapat dijelaskan bahwa biasanya yang menjadi viewers promosi produk di insta story Wellborn adalah perempuan karena dilihat dari banyaknya yang masuk atau mengikuti insta story Wellborn yang memang produk yang di tawarkan dalam istagramnya secara umum bisa di pakai oleh laki-laki dan perempuan. Hal tersebut yang menjadi faktor banyaknya viewers. Bukan hanya itu, pihak Wellborn menyadari dalam segi belanja online atau melihat produk promosi secara online seperti insta story kebanyakan adalah kaum perempuan 
dibandingkan kaum laki-laki disebabkan naluri perempuan dalam belanja baik online maupun tidak sangat tinggi dibandingkan kaum laki-laki. Menurut, Douglas Atkin mengatakan :

Di zaman konvergensi ini, perempuan lebih terpikat terhadap jual beli melalui online seperti website online shop, facebook online shop, twitter online shop, serta melalui media instagram online. Sebanyak $75 \%$ hobi perempuan diera teknologi ini yaitu belanja online di berbagai macam media bisnis online shop yang bagi dirinya menarik maka akan berminat membeli produk yang disukai (Atkin, 20014 : 82)

Dari kutipan tersebut dapat dijelaskan bahwa biasanya yang sering belanja secara online adalah kaum perempuan. Karena pada dasarnya perempuan mempunyai peminatan terhadap belanja secara online sebanyak $75 \%$ di bandingkan kaun laki-laki. Perempuan akan menghabiskan waktu mencari produk yang di sukai dan akan membelinya sesuai dengan seleranya. Salah satu faktor mayoritas perempuan yang menjadi viewers ataupun followers pada insta story Wellborn karena pada dasarnya perempuan lebih menyukai produk, melihatnya, hingga berniat untuk membeli produk jaket Wellborn baik untuk dirinya maupun untuk teman, ataupun keluarga laki-lakinya. Sehingga tidak menutup kemungkinan sekalipun produk Wellborn untuk kaum laki-laki namun pada prakterknya penjualan secara online melalui insta story adalah perempuan sebagai konsumennya di sampai kaum laki-laki.

Sementara mayoritas responden yang menjadi followers, dan menjadi viewers serta mengetahui produk Wellborn sebelum melihat fitur Insta Story Wellborn sebanyak 67 orang atau $100,0 \%$. Berikut ini adalah hasil penelitian yang didapat melalui penyebaran angket kepada responden:

\section{Hubungan Antara Penggunaan Fitur Insta Story dalam Aplikasi Instagram (X) dengan Minat Beli Produk Wellborn (Y)}

Untuk mengukur hubungan antara penggunaan fitur insta story dalam aplikasi instagram (X) dengan minat beli produk Wellborn (Y), berdasarkan koefisien korelasi Pearson antara penggunaan fitur insta story dalam aplikasi instagram dengan minat beli produk Wellborn individu sebesar 0,790. Nilai korelasi sebesar itu menunjukkan bahwa kuatnya hubungan penggunaan fitur insta story dalam aplikasi instagram $(\mathrm{X})$ dengan minat beli produk Wellborn (Y) tergolong hubungan yang kuat. Dengan nilai $\mathrm{t}$ hitung sebesar $(9,818>t$ tabel 2,002), maka disimpulkan terdapat hubungan positif yang signifikan antara penggunaan fitur insta story dalam aplikasi instagram (X) dengan minat beli produk Wellborn (Y). Hal tersebut menunjukkan secara keseluruhan mempunyai hubungan yang kuat, artinya penggunaan fitur insta story dalam aplikasi instagram dapat menciptakan minat beli produk Wellborn. Menurut Douglas Atkin mengatakan:

Minat beli merupakan kumpulan dalam berpikir, keyakinan dan pengetahuan. Disamping itu, sikap memiliki evaluasi positif maupun negatif yang disebabkan oleh komponen afeksi. Semua hal ini dengan sendirinya berhubungan dengan objek atau masalah yang disebut "the attitude object". Pengetahuan dan perasaan yang merupakan kluster dalam sikap akan menghasilkan tingkah laku tertentu. Objek yang dihadapinya pertama-tama berhubungan langsung dengan pemikiran dan penalaran seseorang sehingga komponen kognisi melukiskan objek tersebut dan sekaligus dikaitkan 
dengan objek-objek sekitarnya (Tankard, $2011:$ 451).

Kutipan tersebut dapat dijelaskan

bahwa kuatnya hubungan antara penggunaan fitur insta story dalam aplikasi instagram dengan minat beli produk Wellborn karena clothing Wellborn dalam mempromosikan jaket melalui insta story mempunyai tiga faktor kuat yang dapat mempengaruhi minat konsumen untuk membeli produk jaketnya.

\section{Attraction Fitur Insta Story Produk Wellborn $\left(\mathrm{X}_{1}\right)$ dengan Minat Beli Produk Wellborn (Y)}

Selanjutnya, berdasarkan koefisien korelasi Pearson antara attraction fitur insta story produk Wellborn $\left(\mathrm{X}_{1}\right)$ dengan minat beli produk Wellborn (Y) individu sebesar 0,725. Nilai korelasi sebesar itu menunjukkan bahwa kuatnya hubungan antara attraction fitur insta story produk Wellborn $\left(\mathrm{X}_{1}\right)$ dengan minat beli produk Wellborn (Y) tergolong hubungan yang kuat. Dengan nilai $\mathrm{t}$ hitung sebesar $(8,009>\mathrm{t}$ tabel 2,002), maka disimpulkan terdapat hubungan positif yang signifikan antara attraction fitur insta story produk Wellborn $\left(\mathrm{X}_{1}\right)$ dengan minat beli produk Wellborn (Y). Adanya hubungan yang kuat ini dikarenakan beberapa faktor yang saling mempengaruhi diantara attraction fitur insta story produk Wellborn dengan minat beli produk Wellborn sehingga dalam hal ini dapat memberikan nilai positif baik bagi perusahaan maupun dari viewers atau followers yang melihat insta story clothing Wellborn.

\section{Convert fitur insta story produk Wellborn $\left(\mathrm{X}_{2}\right)$ dengan minat beli produk Wellborn (Y)}

Untuk besarnya koefisien korelasi Pearson antara convert fitur insta story produk Wellborn $\left(\mathrm{X}_{2}\right)$ dengan minat beli produk Wellborn (Y) individu sebesar 0,697. Nilai korelasi sebesar itu menunjukkan bahwa kuatnya hubungan convert fitur insta story produk Wellborn $\left(\mathrm{X}_{2}\right)$ dengan minat beli produk Wellborn (Y) tergolong hubungan yang sedang. Dengan nilai $\mathrm{t}$ hitung sebesar $(7,398>\mathrm{t}$ tabel 2,002), maka disimpulkan terdapat hubungan positif yang signifikan antara convert fitur insta story produk Wellborn $\left(\mathrm{X}_{2}\right)$ dengan minat beli produk Wellborn (Y). Berdasarkan hasil korelasi tersebut mempunyai hubungan yang sedang karena ada beberapa faktor yang menyebabkan hal tersebut salah satunya yaitu tampilan fitur insta story pada produk jaket Wellborn mencirikan bahwa merek Wellborn adalah merek terkena yang kurang dipercayai oleh sebagian viewers ataupun followersnya karena clothing Wellborn masih terbilang baru yang belum tentu merek brand-nya dikenali oleh semua konsumen.

\section{Transform fitur insta story produk Wellborn $\left(\mathrm{X}_{2}\right)$ dengan minat beli produk Wellborn (Y)}

Untuk besarnya koefisien korelasi Pearson antara transform fitur insta story produk Wellborn $\left(\mathrm{X}_{3}\right)$ dengan minat beli produk Wellborn (Y) individu sebesar 0,475. Nilai korelasi sebesar itu menunjukkan bahwa kuatnya hubungan antara transform fitur insta story produk Wellborn $\left(\mathrm{X}_{3}\right)$ dengan minat beli produk Wellborn (Y) tergolong hubungan yang sedang. Dengan nilai $t$ hitung sebesar $(4,115>t$ tabel 2,002), maka disimpulkan terdapat hubungan positif yang signifikan antara transform fitur insta story produk Wellborn $\left(\mathrm{X}_{3}\right)$ dengan minat beli produk Wellborn (Y). Setelah diketahui adanya hubungan antara transform fitur insta story produk Wellborn $\left(\mathrm{X}_{3}\right)$ dengan minat beli produk Wellborn (Y), maka besarnya hubungan dapat diketahui melalui nilai koefisien determinasi. 
Berdasarkan penjelasan di atas adanya hubungan yang sedang hal tersebut dikarenakan kurangnya hubungan antara transform fitur insta story produk Wellborn dengan minat beli produk Wellborn seperti dalam contoh pertanyaan penggunaan fitur insta story Wellborn yang memuat produk jaket itu mendukung minat beli para dewasa awal. Di mana sebagian responden tidak yakin serta kurang percaya bahwa fitur insta story produk jaket Wellborn dapat mempengaruhi dan mendukung minat beli anak muda di usia 18 tahun hingga 40 padalah di usia sebelum 18 tahun serta lebihdari 40 tahun banyak dari viewers ataupun followers berminat terhadap jaket clothing Wellborn.

\section{Diskusi}

Dari penelitian ini ada baiknya attraction penggunaan fitur insta story sebagai media promosi seperti mempertegas brand name clothing Wellborn sebagai bagian dari merek clothing sehingga merek tersebut dapat dikenal dan mudah dilafalkan oleh konsumennya baik viewers, followers maupun

konsumen konvensional. Sementara untuk konsep visual gambar atau foto model yang dikonsep sebaiknya lebih di tingkatkan lagi ide kreatifnya agar dapat menciptakan daya minat beli viewers ataupun followers tehadap produk jaket Wellborn yang ada pada fitur insta story Wellborn. Dari penelitian ini ada baiknya lebih memberikan convert yang mudah dimengerti, simpel, tidak menggunakan bahasa yang susah di cerna baik dalam pembuatan caption pada visual video jaket Wellborn, serta membuat Hashtag yang mudah dimengerti oleh para viewers ataupun followers sebagai konsumennya. Dari penelitian ini ada baiknya pihak clothing Wellborn lebih mengtransform fitur insta story produk jaket baik secara memperbanyak testimoni konsumen yang puas terhadap pelayanan maupun produk jaket Wellborn agar di kemudian hari dapat menciptakan minat konsumennya baik viewers maupun followers serta menciptakan inovasiinovasi baru mengenai tampilan fitur insta story sehingga diharapkan dapat meningkatkan minat beli viewers maupun followers terhadap jaket Wellborn.

\section{Kesimpulan}

1. Terdapat hubungan yang signifikan antara attraction penggunaan fitur insta story sebagai media promosi dengan minat beli produk Wellborn. Hal tersebut dikarenakan beberapa faktor berupa adanya branding atau merek yang di sukai oleh viewers dan followers. Adanya outcome atau hasil yang dapat menciptakan para viewers dan followers memunyai pengetahuan terhadap produk jaket Wellborn serta memberikan opini yang positif terhadap jaket Wellborn dan mengapresiasi pada produk lokal Indonesia yang di produksi oleh clothing tersebut. Dan secara differentiat atau pembeda visual gambar atau foto model yang dikonsep dengan kreatif yang dapat menciptakan minat beli viewers dan followers pada fitur insta story-nya.

2. Terdapat hubungan yang signifikan antara convert penggunaan fitur insta storysebagai media promosi dengan minat beli produk Wellborn. Hal tersebut dikarenakan fitur insta story telah memberikan dampak yang baik sehingga para viewers dan followers berminat untuk 
membeli jaket Welloborn hal tersebut dipengaruhi oleh daya tarik caption, hashtag yang diciptakan oleh clothing Wellborn tersebut.

3. Terdapat hubungan yang signifikan antara transfrom penggunaan fitur insta story sebagai media promosi dengan minat beli produk Wellborn. Hal tersebut dikarenakan clothing Wellborn dapat merubah produk yang laku dipasaran menjadi daya tarik baru bagi perusahaan untuk lebih gencar mempromosikan melalui aplikasi insta story instagram yang salah satunya berupa mengumpulkan testimonial dari konsumen ataupun viewers dan followers berupa caption foto dan komentar-komentar konsumen terhadap produk yang dibeli sehingga mempengaruhi minat beli konsumen karena mereka akan merasa lebih teryakinkan sebab sudah ada orang lain yang mencobanya, dan berhasil untuk membeli jaket Wellborn melalui insta story.

\section{Daftar Pustaka}

Atkin, Douglas, 2014. Membangun Kesetiaan Merek. Yogyakarta: PT. Bintang Pustaka

Effendi, Onong Uchjana. 2003. Ilmu Teori dan Filsafat Komunikasi. Bandung: PT. CitraAditya Bak.

Elvinaro, Ardianto, 2010, Handbook of Public Relations. Bandung : Simbiosa Reklatama Media

Kabani, Shama. 2012. Media Sosial Online Marketing. Terjemahan. Jakarta : Gelora Aksara Pratama

Keller, Kevin Lane. 2003. Manajemen Pemasaran. Jakarta : Gelora Aksara Pratama
Hasan, Iqbal. 2002. "Metode Penelitain dan Aplikasinya". Galia Indonesia. Jakarta.

Rakhmat, Jalaluddin. 2007. "Metode Penelitian Komunikasi". Bandung: Remaja Karya.

Swastha, Basu. 2000. Manajemen Pemasaran Modern. Jakarta: PT. Raja Grafindo Persada

Tankard, 2011 Teori Komunikasi: Sejarah, Metode, dan Terapan di Dalam Media Massa. Jakarta : Kencana Prenada Media Grup 